\title{
Village fund management accountability in Kleseleon village, Weliman district, Malaka regency
}

\author{
Ade Sjan Maikameng ${ }^{*}$, William Djani ${ }^{2}$, Hendrik Toda ${ }^{3}$
}

Master of Public Administration, Nusa Cendana University, Kupang, Indonesia ${ }^{1,2,3}$ olboama@gmail.com ${ }^{1 *}$,williamdjani@gmail.com ${ }^{2}$, hendrik.toda2012@ gmail.com ${ }^{3}$

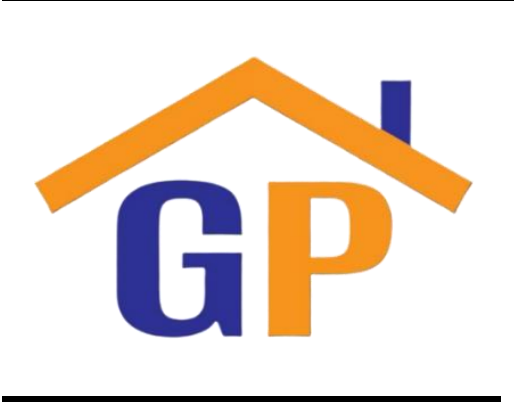

Article History

Received on 21 June 2021

$1^{\text {st }}$ Revision on 1 July 2021

$2^{\text {nd }}$ Revision on 16 July 2021

$3^{\text {rd }}$ Revision on 5 August 2021

Accepted on 10 August 2021

\begin{abstract}
Purpose: This study analyzes the accountability of village fund management in Kleseleon village, Weliman district, Malaka regency.
\end{abstract}

Research methodology: This is qualitative research with a case study approach. Data were collected through observation, interviews and document searches.

Results: There are several problems in managing village funds in Kleseon village, such as delays in determining the program to inefficient reporting. The inhibiting factors for the accountability of village financial management in Kleseleon village are (1) delays in village annual development planning, (2) human resources, (3) facilities, (4) delays in budget allocation and (5) delays in the availability of funds, general guidelines and technical guidelines.

Limitations: This research was conducted relatively quickly so that researchers could not examine more deeply related to the existing problems.

Contribution: The research findings can be used as evaluation material for the Kleseon village government in managing village funds.

Keywords: Accountability, Management, Village

How to cite: Maikameng, A, S., Djani, W., \& Toda, H. (2020). Village fund management accountability in Kleseleon village, Weliman district, Malaka regency. Annals of Management and Organization Research, 2(2), 67-80.

\section{Introduction}

Improving the conditions and living standards of the community in the context of national development in order to achieve just and equitable welfare is the main goal of the government to allocate village funds. The government has a big role in building the country's economy, especially building the regional economy for rural communities. Until now, there are so many programs that the Indonesian government has implemented to improve the living standards of the Indonesian people (Matridi et al. 1, 2019).

In practice, the central government allocates funds and transfers them to the regions. This fund gives the village great authority to manage its own finances and that authority is confirmed in the Village Law Number 6 of 2014 and the fund is referred to as the village fund. In 2016, approximately IDR 628 million (USD 48,300) per village was allocated by the central government for village funds. The total allocation of Village funds increased in 2017, to around IDR 1 billion (USD 76,900), although based on the 2017 RAPBN each village would only receive a total of around IDR 800 million (USD 61,538) (Watts et all, 2019).

Government Regulation of the Republic of Indonesia Number 60 of 2014 concerning Village Funds states that the source of village funds comes from the APBN that is intended for villages, which is 
channeled through the Regency/City APBD. These funds are used to finance the implementation, implementation of development, community development and community empowerment. The village fund management process starts from planning, implementation, administration, reporting and accountability. The principles of transparency, participation and accountability must be the basis of the entire village financial management process.

East Nusa Tenggara Province is one of the 34 provinces that received the village fund budget allocation. The details of the total Village Fund budget allocation in East Nusa Tenggara Province in 2020 are described in the following table:

Table 1. Village Fund Allocation of East Nusa Tenggara Province in 2020

\begin{tabular}{|l|l|l|}
\hline No. & \multicolumn{1}{|c|}{ Regency } & \multicolumn{1}{|c|}{$\begin{array}{c}\text { Total Budget Allocation } \\
\text { (Rp) }\end{array}$} \\
\hline 1. & Alor & 163.156 .591 \\
\hline 2. & Belu & $84,043,335$ \\
\hline 3. & Ende & $198,280,230$ \\
\hline 4. & East Flores & 173.650 .002 \\
\hline 5. & Kupang Regency & $165,133,602$ \\
\hline 6. & Lembata & 131.833 .144 \\
\hline 7. & Manggarai & $149,132,954$ \\
\hline 8. & Ngada & $110,433,806$ \\
\hline 9. & Sikka & $151,300,419$ \\
\hline 10. & West Sumba & 85.550 .126 \\
\hline 11. & East Sumba & $125,908,849$ \\
\hline 12. & South Central Timor & 287.091 .027 \\
\hline 13. & North Central Timor & $160,388,979$ \\
\hline 14. & Rote Ndao & $104,793,226$ \\
\hline 15. & West Manggarai & $147,987,069$ \\
\hline 16. & Nagekeo & $86,209,887$ \\
\hline 17. & Southwest Sumba & 231.558 .590 \\
\hline 18. & Central Sumba & $70,606,507$ \\
\hline 19. & East Manggarai & $198,015,408$ \\
\hline 20. & Sabu Raijua & $85,193,667$ \\
\hline 21. & Malaka & $110,237,185$ \\
\hline
\end{tabular}

Source: dpjk.kemenkeu.go.id (2020)

Based on the table above, there are 21 regencies receiving village fund budget allocations and one of them is Malaka regency with a total budget allocation of Rp. 110,237,185. In Malacca Regency, one of the villages that utilize this village fund budget is Kleseleon village, Weliman district, Malaka regency. 
Kleseleon village itself gets 4 budget sources in addition to income from Village Owned Enterprises (BUMDes), namely village fund allocations (ADD), Village Funds (DD), revenue sharing (BHR) and tax revenue sharing (BHP) from 2018 to 2020 will be explained in the following table:

Table 2. The financial structure of Kleseleon village on 2018 - 2020

\begin{tabular}{|l|l|l|l|l|}
\hline No. & Year & $\begin{array}{c}\text { Village Fund } \\
\text { Amount }\end{array}$ & $\begin{array}{c}\text { Total Village } \\
\text { Fund Allocation }\end{array}$ & $\begin{array}{c}\text { Revenue Sharing and } \\
\text { Regional Levies }\end{array}$ \\
\hline 1. & 2018 & $665,928,000$ & $328,917,000$ & $12.010,000$ \\
\hline 2. & 2019 & 741.070 .000 & $338,868,000$ & $12.463,000$ \\
\hline 3. & 2020 & $734,890,000$ & 321.832 .000 & 9.936 .000 \\
\hline
\end{tabular}

Source: Kleseleon village (2021)

This village financial structure is guided by the technical guidelines set by the Malaka Regent regarding activities financed from village funds. In the technical guidelines, it is explained that the management of village funds should be carried out self-managed using local resources and seeking to absorb more labor from the Kleseleon village community. After obtaining approval from the Malaka Regent, the Village Funds distributed to Kleseleon village can also be used to finance activities that are not included in the priority use of Village funds with the consideration that the allocation of Village funds for priority activities has been fulfilled and/or community empowerment activities have been fulfilled.

In the implementation of budget allocation, there are often delays that have an impact on village development. In the initial observation, the authors found that there were several problems in the accountability of village financial management in Kleseleon village. The phenomenon of financial management accountability problems in Kleseleon village is as follows:

a. Government in Kleseleon village only carry out the programs and activities that have been determined but are still carried out in ways that are not desired according to the targets set so that service delivery is not yet effective as intended previously in its implementation.

b. Programs and activities implemented and expenditures in Kleseleon village have not been effective, efficient and economical and comply with the requirements set out in the applicable laws and regulations. In implementation, it is known that there is a phenomenon of delay in the distribution of village funds, while the delay in the availability of general guidelines and technical guidelines can trigger a potential delay in the start of village development originating from village funds and mismatches in the management of village funds with the proper provisions.

c. Reception are not controlled and used effectively, efficiently and economically in this village.

d. Resources and revenues from audit operations are not calculated and collected properly. This is because the composition of the existing accounting system in the village as a whole related to the requirements, principles and applicable accounting standards has not been implemented effectively and efficiently.

Based on the phenomenon in Kleseleon village related to village financial management, it can be said that the great authority received by the village is accompanied by great responsibility. Therefore, the Kleseleon village government must apply the principle of accountability in the administration of its government where all village government activities must be accountable to the village community in accordance with applicable regulations. In terms of village finances, the village government is obliged to compile a Report on the Realization of the Implementation of the Village Revenue and Expenditure Budget and an Accountability Report on the Realization of the Implementation of the Village Budget. This report is produced from the village financial management cycle starting from the planning and budgeting stages, implementation and administration, to reporting and accountability for village financial management.

The authority and responsibility of Kleseleon village in managing village finances has not been 
balanced with the quantity and quality of adequate human resources (HR). Another obstacle is that Kleseleon village does not yet have procedures and support for facilities and infrastructure in financial management. The village community also has not been able to criticize or be critical of the management of the village income and expenditure budget. The amount of funds that must be managed by the Kleseleon village government has a high level of managing risk, especially for village government officials.

\section{Literature review Accountability}

Accountability is one of the prerequisites for the implementation of good governance. Accountability is one of the government's references in the implementation of public services as stated by Sedarmayanti (2003: 69) that accountability is an obligation to provide accountability or answer and explain the performance and actions of a person or an organization to parties who have the right or authority to request information or accountability.

In the Law of the Republic of Indonesia Number 28 of 1999 Article 3 concerning State Administration that is clean and free from corruption, collusion and nepotism, it is stated that accountability is one part of the general principles of state administration. The principle of accountability in the law means that accountability is the principle that determines that each and the final result of state administration activities must be accountable to the community or the people as the holder of the highest sovereignty of the state in accordance with the provisions of the applicable laws and regulations.

Public administration accountability in a broad sense involves public institutions (agencies) and bureaucrats to control various expectations that come from inside and outside the organization. Thus, public administration accountability is related to the way the public bureaucracy (agencies) realizes public expectations.

Based on several accountability concepts that have been put forward, it can be said that accountability is an important aspect in realizing Good Governance. This shows that accountability is broader than the scope of responsibility outside government alone. Accountability includes the obligation to report on the success or failure of the organization and the management of existing resources. In other words, the public must know all government actions.

\section{Management}

In the Big Contemporary Indonesian Dictionary, the word "Management" comes from the word manage, which means to lead, control, regulate, try to be better or more advanced and be responsible for certain jobs. Meanwhile, Salim and Salim (2002: 534) define management as a process that helps formulate policies and objectives, providing oversight on all matters involved in the implementation and achievement of goals.

Handoko and Basu (1997:8) declare that management is a process that helps formulate an organization's policies and goals or a process that provides oversight to someone involved in the implementation and achievement of goals. It can be concluded from some of the opinions above that management is an activity that starts from planning, organizing, directing and supervising all things involved in implementing and achieving goals. So it can be concluded that management is a method or process that starts from planning, organizing, monitoring and evaluating to achieve a predetermined goal in order to run effectively and efficiently.

\section{Village}

According to the provisions of Article 1 point 1 of Law No. 6 of 2014 regarding villages, villages are defined as traditional villages and villages or other names, hereinafter referred to as villages, which are legal community units that are authorized to regulate and manage government affairs, based on 
Community initiatives, origin rights, and/or the interests of local communities that are traditional rights recognized and respected in the government system of the Republic of Indonesia.

Sukriono (2008:1) expressed his opinion that the lowest government unit in the State of Indonesia is the village. The concept of the village as a social entity is very diverse, namely according to the intent and point of view that will be used in viewing the village. The term village can be a concept without political meaning, but it can also mean a political position and at the same time the quality of the position against other parties or forces

According to Government Regulation Number 43 of 2014 concerning Implementing Regulations of Law Number 6 of 2014 concerning Villages, the village government consists of the village government and village consultative bodies. The village government consists of the village head and village officials. The village head has the task of carrying out government, development and community affairs.

The authorities possessed by the village encourage the village to be more independent, creative and innovative in an effort to improve the welfare of its community, namely by generating initiatives and potentials of existing resources. In carrying out the wheels of government, the village is obliged to be able to improve development, public services and implement village financial management in a good, transparent, and accountable.

\section{Previous research}

Accountability for managing village funds is a much-needed discussion, especially now that village funds continue to be disbursed in order to achieve equitable distribution of the welfare of Indonesian citizens. Several researchers have carried out research related to village fund management accountability. Yulihantini \& Wardayati (2017), in their research entitled Financial Accountability In The Management of Village Fund Allocation, mentions, "The allocations of village fund has an important role in driving the village economy. Therefore this program should be run in accordance with its objectives. In order the implementation of the village fund can run well, need good financial accountability also to ensure that there are no obstacles anymore". Further, Yulihantini \& Wardayati (2017) recommend that 1) The local government should make clear regulations and technical guidelines and continues with giving socialization for the village fund program, 2) To create the fair and equitable principle, village fund sharing formula should be implemented based on the valid government regulations, 3) For the lack of human resource capability, technical guidance regarding the systems and mechanisms are needed, 4) The local government should assist the village governments to coordinate village fund activities for the smooth of village fund implementation, and 5 ). The role of the regional inspectorate to supervise the management of the village fund greatly help the realization of the village fund program management accountability and to reduce the risk of misuse of the village fund program. In a different study, Atmaja and Saputra (2018) state that several factors are the main determinants that determine the accountability of village fund management, namely human resources competence, assistance, and monitoring influence the accountability of village financial management. Atmaja and Saputra (2018) further emphasized that the most important aspect in maintaining and supporting the accountability of village fund management is monitoring from the local government. Good monitoring will certainly create a reliable management of village funds.

\section{Research methodology}

The method used in this research is a qualitative research method with a case study approach. The types of data in this study are qualitative data and quantitative data. Sources of data in this study are primary data and secondary data. Data collection techniques are observation, interviews and document searches. The informants were determined purposively with a total of 35 people. For analyze the success rate of village financial management accountability in Kleseleon village, the author uses analytical indicators based on the type of program accountability from Carino (1993:544) with indicators of analysis of audit implementation village financial management in Kleseleon village consisting of (a) Determination of programs and activities, (b) Implementation of programs and 
activities, (c) Budget receipts, (d) Budget audit operations, (e) Accountability and (f) Reporting of operating results and financial statements. The level of achievement of the results (through performance audits) and the level of acceptance of the results are indicated by people's satisfaction with the results.

\section{4, Results \\ Village financial management accountability in Kleseleon village, Weliman district, Malaka regency}

For analyzing the success rate of accountability for village financial management in Kleseleon village, the author uses analytical indicators based on the type of program accountability from (Carino, 1993:544) with indicators of analysis of audit implementation village financial management in Kleseleon village includes:

\section{Determination of programs and activities}

It is known that the procedure for planning village funds in Kleseleon village is that the village headfirst reports to the community that a hamlet meeting will be held from each hamlet in Kleseleon village. After that up to the village level which was held in October and the next step is Sub-District Community Disussion Devolopment Planning (Musrembangcam) stage and was ratified and then the Draft Village Goverment Budget (RAPBDes) was drafted and then brought to the district level. The community, Village Deliberation Agency (BPD), Community Empowerment Board (LPM) together with Village Facilitators, attended this planning stage. So it can be concluded that the government in Kleseleon village only implements the programs and activities that have been set.

Another finding in the results of observations and document searches carried out by the author is that there are often delays in the planning stages of the Village Annual Development. To note that the Village Annual Development Plan or the so-called Village Government Work Plan is for the first period of the year and is an elaboration of the Village Medium-Term Development Plan. Development Planning in Kleseleon village compiled based on the results of an agreement in a village meeting whose implementation was no later than June of the current budget year, but in Kleseleon village this activity was carried out in October so that it was 3 months late from the time stipulated in the law. The Village RKP began to be compiled by the Village Government in July of the current year and had to be determined no later than September of the current budget year but in Kleseleon village, the planning stage with the preparation and determination of the village RKP was carried out in December while the Village RKP became the basis for the preparation of the Village APB draft (RAPB Desa) resulting in delays in the distribution of village funds for Kleseleon village.

Findings related to the phenomenon of delay in the planning stage of village fund management in Kleseleon village are an irony because, with large amounts of funds, it is hoped that the use of village funds can provide more space for the community for Kleseleon village to actively participate in planning, implementation and accountability. This is carried out in order to implement the basic concept of the level of participation of the Kleseleon village community, but it will not be effective if the planning activities that should have been determined even exceed the stipulated time limit while all activities funded by village funds must be planned in a timely and effective manner and implemented and supervised openly by involving all elements of the village community for the implementation of good governance.

Punctuality is needed from the planning stage because Target clarity partially has a positive and significant effect on performance accountability according to (Surya and Syukriy, 2019). At the planning stage of this village fund, according to Terry (2006: 342), it is necessary to select facts and attempt to relate the facts to one another, then make estimates and forecasts about the situation and formulate future actions if needed to achieve the desired results in line with the results with a management function which is a process of directing and providing work facilities to people who are organized informal groups to achieve goals (Burhanuddin, 1994: 34) but this activity will be hampered when it is not based on the timeliness of planning that should be carried out as happened in Kleseleon village. 
2. Implementation of programs and activities

The village government uses the APBDes funds to finance the implementation of village authority in the form of various development activities and village community empowerment, but according to the observations made by the author, it is known that the programs and activities implemented and expenditures in Kleseleon village are made of poor quality, one of which is quality of the construction of village roads which the authors value is not good so that the authors can state that the quality of programs and activities carried out as well as expenditures in Kleseleon village are made in a way that is not yet effective, efficient and economical.

The development quality of Kleseleon village seems to be a paradox because the start of the village funds basically runs counter to the desire for changes in the village. Therefore, the Government of the Republic of Indonesia has formulated a law that adapts to the village regulations, namely the Republic of Indonesia Law No. 6, 2014 regarding village laws, new paradigms and concepts for implementing village governance policies nationwide have been adopted. The village law no longer uses the village as the background of Indonesia but the front page of Indonesia. It contains various government programs promoting village welfare. One of them is to allocate village funds. However, in the use of Kleseleon village, these villages the funds failed to make the community prosperous.

In addition, the main objective of the government program through the allocation of village funds is to improve the conditions and standard of living of the community in the context of national development in order to achieve just and equitable welfare, which is a tangible manifestation of the central government's attention to the lower level government, namely the village government. The benefits are very large for the community if it is used properly by Kleseleon village (Matridi et al. 1, 2019), especially to build the economy of the village community or Kleseleon village; it is necessary to have further questions regarding the accountability of village fund management in Kleseleon village. The existence of such accountability is a form of transparency of activities carried out and all policies implemented. Accountability is not only limited to being responsible for the results in writing through periodic reports but its real implementation in Kleseleon village.

In article 3 of the Law of the Republic of Indonesia, Number 28 of 1999 , concerning the implementation of a clean and free from corruption, collusion, and nepotism, accountability is one part of the general principles of state administration. The principle of accountability in the law means that accountability is the principle that determines that each and the final result of state administration activities, especially utilization and villages in Kleseleon village, must be accountable to the community or the people as the holder of the highest sovereignty of the state in accordance with the provisions of the applicable laws and regulations.

\section{Budget receipt}

Based on the author's observations, it is known that Kleseleon village gets 4 (four) budget sources other than income from BUMDes, namely village fund allocations (ADD), Village Funds (DD), retribution revenue sharing (BHR) and tax revenue sharing (BHP). This village finance is guided by the technical guidelines set by the Regent of Malaka regarding activities financed from Village funds and preferably carried out self-managed using local resources/raw materials, and strived to absorb more labor from the Kleseleon village community.

Village funds disbursed for Kleseleon village can be used to finance activities that are not included in the priority use of Village funds after obtaining approval from the Malaka Regent by ensuring that the allocation of Village funds for priority activities has been fulfilled and/or community development and empowerment activities have been fulfilled. Based on this explanation, the total allocation of village funds (ADD), Village Funds (DD), retribution sharing revenue (BHR) and tax sharing revenue (BHP) from 2018 to 2020 will be described in the following table: 
Table 3. Kleseleon village financial structure for 2018 to 2020

\begin{tabular}{|l|l|l|l|l|}
\hline No. & Year & \multicolumn{1}{|c|}{$\begin{array}{c}\text { Village Fund } \\
\text { Amount }\end{array}$} & $\begin{array}{c}\text { Total Village Fund } \\
\text { Allocation }\end{array}$ & $\begin{array}{c}\text { Revenue Sharing and } \\
\text { Regional Levies }\end{array}$ \\
\hline 1. & 2018 & $665,928,000$ & $328,917,000$ & $12.010,000$ \\
\hline 2. & 2019 & 741.070 .000 & $338,868,000$ & $12.463,000$ \\
\hline 3. & 2020 & $734,890,000$ & 321.832 .000 & 9.936000 \\
\hline
\end{tabular}

Source: Kleseleon village (2021)

Based on the table above, it is known that every year Kleseleon village gets a large enough budget allocation to facilitate the development process in Kleseleon village. However, in its implementation, this budget allocation often occurs delays, so that it has an impact on the development of Kleseleon village itself. In contrast, This very large allocation of funds is expected to have a significant impact on the welfare of the Kleseleon village community and can actually be reported and accounted for based on the principles of good governance, namely transparent, participatory and accountable. This central government assistance village fund should also be utilized as optimally as possible to build physical facilities and infrastructure that can help villagers improve their economy. Therefore, the distribution and management must be monitored down to the village level so that there is no misuse of these funds, but in the allocation, there are often delays.

Other problems in the Village Government Work Plan (RKP Desa) or also called the Kleseleon village Annual Development Plan, physically the construction of a village office fence that is not good, hand tractors for the community that are left damaged, village office toilets that do not have doors, village offices whose roofs are damaged. The accountability of the village government, as stated by Carino (1993:544) through program accountability, is carried out in the administration of government in accordance with the principle of accountability. Mahmudi (2013:9) states that Program Accountability is an evaluation of the goals that have been set can be achieved or not and provide alternative programs that can provide optimal results with minimal costs, but in Kleseleon village the program that has been run has not been able to provide optimal results at minimum cost.

From the results of the authors' findings when conducting this research, it can be concluded that the receipt of village funds in Kleseleon village is not sufficiently controlled because in 2019 there were $741,070,000$ while the allocation of village funds was 338,868,000, in 2020 the receipt of Kleseleon village funds was $734,890,000$ and the allocation of village funds of $321,832,000$ so that each program contained in the Kleseleon village Government Work Plan (RKP) for 2019 and 2020 has not been used effectively, efficiently and economically. Because of this budget allocation, delays often occur so that which has an impact on the period of program implementation and the development of Kleseleon village is in a hurry, causing the quality of physical activities in Kleseleon village not to be maximized.

The delay in the availability of these general guidelines and technical guidelines can trigger a potential delay in the start of village development originating from village funds and the mismatch of village fund management with the proper provisions. In the distribution of village funds stage 1 in 2020 , it is known that there is a delay so that it also affects the community less than the maximum absorption or realization of the use of village funds which resulted in the not yet maximal absorption of funds for the development of Kleseleon village and the submission of a report on the realization of the implementation of the first-semester APBDes which was not in accordance with the reporting schedule. This is inversely proportional to the rules for the reporting system on the realization of the APBDes implementation as stipulated in the Regulation of the Minister of Home Affairs of the Republic of Indonesia Number 113 of 2014 concerning Village Financial Management which states 
that the submission of a report on the realization of the implementation of the APBDes in the first semester is submitted no later than the end of July of the current year with the realization the use or absorption of the budget is at least 50\% (fifty percent). However, the village fund manager cannot carry this out because until August 2020, the absorption of Kleseleon village funds was only $43.79 \%$. The Kleseleon village apparatus reasoned that due to the delay in disbursing funds and very limited time, it was not possible for village fund managers to immediately realize the use of funds. In this cycle, village financial management is the responsibility and task of the apparatus, namely the village secretariat, regional executive, and technical implementer.

\section{Budget check operation}

The statement based on the findings of the author's research is in line with the results of the analysis of Dekeng and Devi (2020), which shows that management commitment has a significant effect on accountability and transparency and regulation, has a significant effect on transparency. Transparency, in this case, is that all resources and revenues from audit operations are calculated and collected appropriately in Kleseleon village, and this is an important part of realizing good governance.

Resources and revenues from audit operations are calculated and collected appropriately as well as regulated in Article 3 of the Law of the Republic of Indonesia Number 28 of 1999 concerning the implementation of a clean and free from corruption, collusion, and nepotism is states that accountability is one part of the general principles of state administration. The principle of legal accountability means that accountability is the principle that determines the responsibility of the public for each of the national administrative activities and the final results. On the billboard in Kleseleon village, the resources and income from the inspection operation were accurately calculated and collected.

\section{Accountability}

The focus of accountability refers to the composition of the overall accountability system in Kleseleon village in relation to the requirements, principles and standards of accountability that have been established. In practice, the overall accountability system structure in Kleseleon village is managed based on good governance practices and must be based on the Village Financial Management Principles as stated in Permendagri Number 113 of 2014, which is transparent, accountable, Participatory and carried out in an orderly and budgetary discipline.

Based on the results of interviews and observations made by the author in Kleseleon village, it was found that the composition of the overall accounting system in Kleseleon village related to requirements, principles and applied accounting standards had not been implemented effectively and efficiently. In Kleseleon village, the village financial manager, in this case, the village treasurer, still does not understand the tax deposit system with the e-billing application. This causes delays in depositing taxes so that in its application, the accountability of fund management in Kleseleon village has not met the goals and objectives that have been set. Previously, there was also no information through notification letters or socialization from the relevant agencies, namely KPP Pratama, so that the tax payment made by the village treasurer was delayed and eventually became the findings of the inspectorate. The communication factor is very important to support the success of this village financial management accountability. In addition, the village government must be able to keep records, or at least keep books of financial transactions, as a form of financial accountability. In addition, village-level financial management requires honesty, objectivity, transparency and accuracy in management. Village finance is the management of all rights and obligations of the village government, which can be measured by money.

For this reason, in managing village finances, the Kleseleon village Government needs to account for the administration of government to the community according to applicable accounting principles and standards so that it will be an ironic finding when the Kleseleon village treasurer as the financial person in Kleseleon village does not understand the requirements, principles and applicable accounting standards in the management of village funds. Meanwhile, to achieve the effectiveness of 
the village fund program in Kleseleon village, several facilities must be provided, including comprehensive performance measurement. However, this measurement will not be optimal if the accountability mechanism for managing village funds is not understood by policy implementers so that it is not in line with the Presidential Instruction of the Republic of Indonesia Number 7 of 1999 concerning Work Accountability of Government Agencies.

The Kleseleon village head in carrying out the management of village funds is assisted by PTPKD, who comes from elements of the village apparatus, one of which is the village treasurer with the task of administering accountability reports. However, in preparing the accountability report, there are still things that are not understood by the village treasurer. This is due to the lack of understanding of the village treasurer regarding regulations and the lack of knowledge and information to support his duties. The level of ability of the village treasurer still needs to be pursued to increase competence. These competencies are a combination of motivation, attitudes, character, knowledge and abilities that must always be strived for continuous improvement.

Based on the phenomenon of the village and Kleseleon financial management, the big role played by the village is, of course, accompanied by great responsibility. Therefore, the Kleseleon village government must be able to apply the principle of accountability in the administration of its government, and the completion of all village government activities must be accountable to the village community in accordance with applicable regulations. In terms of village finances, the village government is obliged to compile a report on the implementation of the APBDes and an accountability report for the implementation of the APBDes. This report is produced from the village financial management cycle, starting from the planning and budgeting stages, implementation and management, to the reporting system and accountability for village financial management.

\section{Reporting on operating results and financial statements}

The level of achievement of the results (through performance audits) and the level of acceptance of the results are indicated by people's satisfaction with the results. The accountability of the village government, as stated by Carino (1993:544) through program accountability, is carried out in the administration of government in accordance with the principle of accountability. The main principle of accountability is accountability to the public. For this reason, the government, including the Kleseleon village Government, needs to be accountable for the administration of government to the community, especially in terms of managing village finances.

Based on the results of observations and testing of the validity of the data carried out by the author, it is known that the operational reporting and financial statements in Kleseleon village as a whole have not disclosed the information needed correctly where at the planning and budgeting stages, the operating reporting mechanism and financial statements have not been carried out either to the Consultative Body. Village (BPD) as well as to the village community so that there are still people in Kleseleon village who are not satisfied with the performance of village officials. This happened because the village treasurer faced an obstacle where the activity management team (TPK) did not comply with the commitment of the mechanism for recording village financial receipts and expenditures. The TPK was often late in submitting the evidence or documents required by the treasurer to record every receipt and expenditure, the results of which became one reporting and accountability document. Meanwhile, every receipt and expenditure in the implementation of activities must go through the verification of the village secretary, whose job is to verify the evidence of APBDes receipts and expenditures. This phenomenon is in accordance with what was stated by Indriyono et al. (2002:8) that accountability in the public sector is not an easy thing. It takes morals, values, and attitudes from government officials who are responsible for managing public funds. If an individual commits to certain goals, then this will affect his actions and affect the consequences of his performance (Suartana, 2010: 181).

Factors inhibiting the achievement of village financial management accountability in Kleseleon village, Weliman district, Malaka regency

With a large number of funds, it is hoped that the use of village funds can provide more space for the 
community to actively participate both in planning, implementation and accountability. This is also expecting to be implemented properly in Kleseleon village, but based on the results of the author's research. It was found that in its implementation, there are factors. The obstacles to achieving village financial management accountability in Kleseleon village are as follows:

\section{Delay in annual village development planning}

Please note that the annual village development plan or the so-called village government work plan (RKP Desa) lasts for one (one) year and is a detailed description of the village's mid-term development plan. The development plan of Kleseleon village was prepared based on the results of the agreement reached by the village meeting. The implementation time of the plan was no later than June of the current budget year. However, in Kleseleon village, this activity was carried out in October, so it was lower than the current budget. The annual implementation was 3 months late-the time required by law. The village RKP was prepared by the village government in July of that year and must be determined no later than September of the current budget year. However, in Kleseleon village, preparations and determinations were made. The planning stage of the village RKP was withdrawn in December, and the village RKP became the preparatory village APB. Based on the draft (RAPB Desa), the distribution of rural funds in Kleseleon village was delayed.

\section{Human resources}

In the context of this research, human resources will be reflected in the personnel or employees involved in the successful accountability of village fund management in Kleseleon village. However, in compiling the accountability report, the village treasurer still does not understand the regulations and information to support his duties which in the end causes the operational reports and financial statements in Kleseleon village as a whole not to disclose the information needed correctly so that the Village Consultative Body (BPD) and the village community Kleseleon has not been satisfied with the performance of village officials.

Other than that, the activity management team (TPK) did not comply with the commitment to the mechanism for recording village financial receipts and expenditures. The TPK was often late in submitting the evidence or documents required by the treasurer to record every receipt and expenditure, the results of which became one reporting and accountability document. Meanwhile, every receipt and expenditure in the implementation of activities must go through the verification of the village secretary, whose job is to verify the evidence of APBDes receipts and expenditures.

\section{Facilities}

In its implementation in Kleseleon village, one of the inhibiting factors for village financial management accountability is the availability of facilities in the form of facilities and infrastructure that support the success of accountability where the Kleseleon village Office does not have toilets and the quality of buildings that are partially damaged and the lack of laptops as a medium for recording and reporting as well as accountability for use. Village funds, while an institutional unit that in this case is the Kleseleon village Office must have a workspace consisting of a place, personnel and a laptop as a medium for reporting operations and overall financial statements to properly disclose the required information.

\section{Budget allocation delay}

Based on the research, it is known that the budget allocation in Kleseleon village often experiences delays in its distribution to the village, so that it has an impact on the period of program implementation and development of Kleseleon village. Village funds in Kleseleon village in 2019 amounted to $741,070,000$ while the allocation of village funds was $338,868,000$, in 2020 Kleseleon village fund receipts amounted to 734,890,000 and village fund allocations amounted to 321,832,000 so that each program contained in the Government Work Plan Kleseleon village (RKP) in 2019 and 2020 have not been used effectively, efficiently and economically.

In the distribution of village funds stage 1 in 2020 , it is known that there is a delay so that it also affects the community less than the maximum absorption or realization of the use of village funds 
which resulted in the not yet maximal absorption of funds for the development of Kleseleon village and the submission of a report on the realization of the implementation of the first-semester APBDes which was not in accordance with the reporting schedule. This is inversely proportional to the rules for the reporting system on the realization of the APBDes implementation as stipulated in the Regulation of the Minister of Home Affairs of the Republic of Indonesia Number 113 of 2014 concerning Village Financial Management which states that the submission of a report on the realization of the implementation of the APBDes in the first semester is submitted no later than the end of July of the current year with the realization the use or absorption of the budget is at least $50 \%$ (fifty percent). But, this cannot be carried out by village fund managers because until August 2020, the absorption of Kleseleon village funds was only $43.79 \%$. Kleseleon village officials reasoned that due to delays in disbursing funds and very limited time, it was not possible for village fund managers to immediately realize the use of funds budget so that revenue has not been controlled and used effectively efficiently and economically in Kleseleon village.

\section{Delay in the availability of general guidelines and technical guidelines}

The delay in the availability of these general guidelines and technical guidelines can trigger a potential delay in the start of village development originating from village funds and the mismatch of village fund management with the proper provisions. In the distribution of village funds stage 1 in 2020 , it is known that there is a delay so that it also affects the community less than the maximum absorption or realization of the use of village funds which resulted in the not yet maximal absorption of funds for the development of Kleseleon village and the submission of a report on the realization of the implementation of the first-semester APBDes which was not in accordance with the reporting schedule. This is inversely proportional to the rules for the reporting system on the realization of the APBDes implementation as stipulated in the Regulation of the Minister of Home Affairs of the Republic of Indonesia Number 113 of 2014 concerning Village Financial Management which states that the submission of a report on the realization of the implementation of the APBDes in the first semester is submitted no later than the end of July of the current year with the realization the use or absorption of the budget is at least 50\% (fifty percent). However, the village fund manager cannot carry this out because, until August 2020, the absorption of Kleseleon village funds was only $43.79 \%$. The Kleseleon village apparatus reasoned that due to the delay in disbursing funds and very limited time, it was not possible for village fund managers to realize the use of funds immediately. In this cycle, village financial management is the responsibility and task of the apparatus, namely the village secretariat, regional executive, and technical implementer.

\section{Conclusion}

Based on the results of the research, it can be concluded that accountability of village financial management in Kleseleon village is based on program accountability indicators from Carino (1993: 544), namely (a) At the stage of determining programs and activities there are often delays, (b) The implementation of programs and activities had not been effective, efficient and economical where physical development in Kleseleon village using village funds was made with less than good quality (c) Budget receipts in the form of Village fund budget allocations are often late and uncontrolled so that it has an impact on the development of Kleseleon village, (d) Accountability in Kleseleon village includes requirements, principles and standards of accountability that are still not effective because the village treasurer does not yet understand the tax payment system with the e-billing application, (e) operational reports and financial statements in Kleseleon village as a whole have not disclosed the necessary information appropriately where at the planning stage and the preparation of the budget for operating reporting mechanisms and financial statements has not been carried out either to the Village Consultative Agency (BPD) or to the village community so that there are still people in Kleseleon village. Factors for accountability of village financial management in Kleseleon village are (1) delay in village annual development planning, (2) human resources, (3) facilities, (4) delays in budget allocation and (5) delay in the availability of general guidelines and technical guidelines. 


\section{References}

Atmadja, A. T., \& Saputra, K. A. K. (2018). Determinant factors influencing the accountability of village financial management.Academy of Strategic Management Journal, 17(1), 1-9.

Burhanuddin. (1994). Analisis administrasi,manajemen dan kepemimpinan guru di. Indonesia. Jakarta. Bumi Aksara

Carino. L. V. (1993). Accountability, Corruption and Democracy. Manila: Philippines Institute for Developments.

Dekeng Setyo Budiarto, Devi Damayanti. (2020). Pengujian struktural pada komitmen manajemen, transparansi dan akuntabilitas pemerintah daerah. Accounting Study Program, Faculty of Economics and Business, Universitas Sebelas Maret, Indonesia. http://dx.doi.org/10.20961/jab.v20i1.508

Direktorat Jendral Perimbangan Keuangan Kementrian Keuangan. (2020). Perubahan Alokasi Transfer ke Daerah dan Dana Desa TA 2020 dalam Peraturan Menteri Keuangan No. 35/PMK.07/2020. Diakses 30 Juni 2021 dari http://www.djpk.kemenkeu.go.id/?p=15023

Handoko T. Hani dan Basu Swastha DH. Hani. (1997). Manajemen pemasaran,. Analisa Perilaku Konsumen. Yogyakarta. Liberty

Indriyo Agus, Gitusudarmo dan Basri. (2002). Manajemen keuangan. Yogyakarta. BPFE.

Mahmudi. (2013). Manajemen kinerja sektor publik. Sekolah Tinggi Ilmu. Manajemen Yogyakarta. YKPN.

Matridi, Abumanshur Raja Dedi Zuraidi, Rendra Setyadiharja, Endri Sanopaka, Desrian Effendi, Diah Siti Utari. (2019). An Evaluation of P3DK (An Acceleration of Development Village Program): A Reviewing on Failure toward Revolving Loan Fund System in Kepulauan Riau Province, Indonesia. 1011-3291/2019 The Author(s). Published by Elsevier Ltd. http://creativecommons.org/licenses/by-nc-nd/4.0/

Pemerintah Desa Kleseon. (2021). Struktur Keuangan Desa Kleseon Tahun 2018-2020. Kantor Desa Kleseon.

Pemerintah Republik Indonesia. (1999). Instruksi Presiden Republik Indonesia Nomor 7 Tahun 1999 Tentang Akuntabilitas Kerja Instansi Pemerintah Republik Indonesia. Sekertaris Kabinet Republik Indonesia. Jakarta.

Pemerintah Republik Indonesia. (1999). Undang-Undang Republik Indonesia Nomor 28 tahun 1999 Tentang Penyelenggaraan Negara Yang Bersih Dan Bebas Dari Korupsi, Kolusi dan Nepotisme. Lembaran Negara No.75 Tahun 2014. Sekertariat Negara. Jakarta.

Pemerintah Republik Indonesia. (2014). Peraturan Menteri Dalam Negeri Republik Indonesia Nomor 113 Tahun 2014 tentang Pengelolaan keuangan Desa. Berita Negara No. 2093 Tahun 2014. Kementrian Dalam Negeri Republik Indonesia. Jakarta.

Pemerintah Republik Indonesia. (2014). Peraturan Pemerintah Republik Indonesia Nomor 43 Tahun 2014 tentang Peraturan Pelaksanaan Undang-undang Nomor 6 Tahun 2014 tentang Desa. Lembaran Negara No.113 Tahun 2014. Sekertariat Negara. Jakarta

Pemerintah Republik Indonesia. (2014). Peraturan Pemerintah Republik Indonesia Nomor 60 Tahun 2014 tentang Dana Desa. Lembaran Negara No.168 Tahun 2014. Sekertariat Negara. Jakarta.

Pemerintah Republik Indonesia. (2014). Undang-Undang Republik Indonesia Nomor 6 Tahun 2014 Tentang Desa. Lembaran Negara No.7 Tahun 2014. Sekertariat Negara. Jakarta.

Salim, Peter dan Salim Yenny. (2002). Kamus bahasa indonesia kontemporer. Jakarta. Modern English Press

Sedarmayanti. (2003). Good govenance (kepemerintahan yang baik). dalam rangka otonomi daerah. Bandung. Mandar Maju

Suartana, I Wayan. (2010). Akuntansi keperilakuan teori dan implementasi. Yogyakarta. Penerbit Andi.

Sukriono Didik. (2008). Politik hukum pemerintahan desa di Indonesia. Jurnal Konstitusi, 1. Malang. PKK Universitas Kanjuruhan Malang

Surya Benediktus Manullang dan Syukriy Abdullah. (2019). Pengaruh Pengendalian Internal, Kejelasan Sasaran Anggaran dan Pergantian Kepala SKPD Terhadap Akuntabilitas Kinerja. Jurnal Ilmiah Mahasiswa Ekonomi Akuntansi (JIMEKA), 4(1), 62-73

Terry George R., (2006). Principles of management. (Alih bahasa winardi), Alumni. Bandung 
Watts John D, Luca Tacconi, Silvia IrawanAklan, H. Wijaya. (2019). Village transfers for the environment: Lessons from community-baseddevelopment programs and the village fund. 13899341/ (C) 2019 Elsevier BV This is an open access article under the CC BY-NC-ND licens. https://doi.org/10.1016/j.forpol.2019.01.008

Yulihantini, D. T., \& Wardayati, S. M. (2017). Financial accountability in the management of village fund allocation. 